J. Product. \& Dev., 12(1): 85 - 99(2007)

\title{
EFFECT OF IRRIGATION INTERVALS AND BIOFERTILIZATION ON YIELD, OIL PRODUCTION AND CHEMICAL CONSTITUENTS OF CHAMOMILE (Matricaria chamomilla,L.) PLANTS.
}

A. S. M. EL-Leithy

Ornamental Horticulture Department, Faculty of Agriculture, Cairo University, Egypt.

\section{ABSTRACT}

The present study was conducted during the two successive seasons of 2002/2003 and 2003/2004 at the Farm of Ornamental Horticulture Department, Faculty of Agriculture, Cairo University to investigate the effect of irrigation intervals every 7, 11 or 15 days and bio-fertilizers (Nitrobien and Phosphorein) each at 0, 3 or $6 \mathrm{~g} /$ pot on chamomile plant. The results showed that prolonging irrigation interval to 11 or 15 days significantly decreased both fresh and dry weights of flowers in both seasons. The highest fresh and dry weights of flowers were obtained due to irrigation every 7 days . Irrigation every 7 or 11 significantly increased oil percentage in the first and second seasons ,respectively. Irrigation every 7 days gave the highest $\alpha$ pinene, sabinene, $\rho$ cymene, 1,8-cineole, bisabolon oxide A, chamazulene and dicycloether. Whereas irrigation every 11 days gave the highest percentage of bisabolol oxide A. Irrigation every 11days gave the highest $N$ contents, while irrigation every 15 days gave the highest $P$ and $K$ contents. Irrigation every 7 days gave the highest total carbohydrates content.

In general, Nitrobien and Phosphorein application at 3 or $6 \mathrm{~g} / \mathrm{pot}$ significantly increased fresh and dry weights of flowers. Nitrobien at 3 or $6 \mathrm{~g} /$ pot in both seasons and Phosphorein at 3 or $6 \mathrm{~g} / \mathrm{pot}$ in the second season significantly decreased oil percentages. Nitrobien at 3 or $6 \mathrm{~g} /$ pot gave the highest bisabolol oxide A contents in chamomile oil. Whereas Phosphorein at 3 $g$ /pot resulted in the highest $\rho$ - cymene, 1,8-cineole and caryophyllene percentages. Phosphorein at the highest rate (6 $\mathrm{g} /$ plant) gave the highest $\alpha$ pinene, sabinene and chamazulene contents. Bio-fertilizers ( Nitrobien or Phosphorein ) each at 3 or $6 \mathrm{~g} /$ pot increased both $N, P, K$ and total carbohydrates contents in most cases compared with the control. Both Nitrobien and Phosphorein at $6 \mathrm{~g} /$ pot plus irrigation every 7 days gave the highest fresh and dry weights of flowers. Irrigation every 11 days and Phosphorein at $6 \mathrm{~g} / \mathrm{pot}$ gave the highest oil \% in the first season and $P \%$ in the second one. Nitrobien at $6 \mathrm{~g}$ /pot plus irrigation every 15 days gave the highest N\%. Whereas Phosphorein at 3 or $6 \mathrm{~g} /$ pot and irrigation every 7 days gave the highest $K$ and carbohydrates contents.

Keywords: Irrigation intervals, biofertilization, oil production, chemical constituents, chamomile plants. 


\section{INTRODUCTION}

Chamomile (Matricaria chamomilla, L.) is an annual, strongly aromatic herb, up to $60 \mathrm{~cm}$ tall with a hairless, erect, branching stem. It has delicate feathery leaves and simple daisy- like white flowers. This herb has a long standing medicinal tradition, especially in Europe for all states of tension and the visceral symptoms that can arise there form, such as nervous dyspepsia and nervous bowel, tension headaches, and sleeplessness. It is used as analgestic, anti-allergenic, antiinflammatory, antispasmodic, bactericidal, carminative, cicatrisant, cholagouge, digestive, emmmenagogue, febrifuge, fungicidal, nerve sedative, stimulant of leucocyte production, stomachic, vermifuge. It is used externally in cosmetics ,soaps, detergents, high class perfumes and hair and bath products. It is used in skin care against boils, burns , cuts, dermatitis , earache, eczema, hair care, sensitive skin, teething pain, toothache, wounds (Lawless,1992). Massoud and Franz (1990) mentioned that different chemocultivars of chamomile are presented on the market, which differ in the composition of the essential oil .For example, bisabolol A- type presented in Egypt, Czech. Rep. and Hungary, bisabolol-type is presented in Spain and bisabolon oxide type is presented in Turkey and Bulgaria.

Irrigation intervals affecting growth and chemical constituents of many aromatic plants, Ahmed and El-Hassen (2001) on Catharanthus roseus; Hammoda (2001) on moghat plants; Singh and Sharma (2001) on Cymbopogon martinii; Hammam (2002) on Cassia acutifiolia; Mazrou et al. (2002) on roselle; Mahmoud et al. (2002) on Grindelia camporum; Yassen et al. (2003) on Ocimum basilica,L; Singh (2004) on rosemary; Mastro et al. (2004) on artichoke and chicory and Akbarinia et al. (2005) on Nigella sativa plants.

The bio-fertilizers are much more likely to increase both yield and quality and producing plants that are safe flavor some, and chemicals free. Salman (2004) on Ocimum basilicum L.; Saraf and Tiwari (2004) on muskdana (Abelmoschus moschatus); Youssef et. al.(2004) on sage; Zayed et al. (2004) on Borago officinalis, L.; Migahed et al. (2004) on celery; Shalan (2005) on borage plants; Heikal(2005) on thyme and Sakr (2005) on senna plants.

\section{MATERIALS AND METHODS}

The present study was conducted during the two successive seasons of 2002/2003 and 2003/2004 at the Farm of Ornamental Horticulture Department, Faculty of Agriculture, Cairo University to investigate the effect of irrigation intervals and bio- fertilizers on chamomile ( Matricaria chamomilla, L.) plant.

Seeds of chamomile were sown in nursery beds with a clay soil on $4^{\text {th }}$ October in the two seasons. After 45 days, the seedlings $(8-10 \mathrm{~cm}$ in height $)$ were transplanted in $30 \mathrm{~cm}$ clay pots ( one plant / pot) filled with sandy loam soil (Table A) on $19^{\text {th }}$ November in both two seasons. 15 days.

After two weeks from transplanting, the plants were irrigated every 7, 11 or 
Table A. Chemical and physical properties of the experimental soil.

\begin{tabular}{lccc}
\hline \multicolumn{4}{c}{ Physical properties of the experimental soil. } \\
\hline Seasons & $\begin{array}{c}\text { Sand } \\
\mathbf{\%}\end{array}$ & $\begin{array}{c}\text { Clay } \\
\mathbf{\%}\end{array}$ & $\begin{array}{c}\text { Silt } \\
\mathbf{\%}\end{array}$ \\
\hline $\begin{array}{l}\text { Sandy loam } \\
\mathbf{2 0 0 2 / 2 0 0 3}\end{array}$ & 55.2 & 18.5 & 26.3 \\
\hline $\begin{array}{l}\text { Sandy loam } \\
\mathbf{2 0 0 3 / 2 0 0 4}\end{array}$ & 54.9 & 19.2 & 25.9 \\
\hline
\end{tabular}

Chemical properties of the experimental soil.

\begin{tabular}{|c|c|c|c|c|c|c|c|c|c|c|c|c|c|}
\hline \multirow[b]{2}{*}{ Seasons } & \multirow[b]{2}{*}{ pH } & \multirow[b]{2}{*}{$\begin{array}{l}\mathbf{E C} \\
*\end{array}$} & \multicolumn{8}{|c|}{ Soluble cations and anions (meq / L) } & \multicolumn{3}{|c|}{ Available (ppm) } \\
\hline & & & 'ீ & $\overbrace{}^{1}$ & $\bar{v}$ & ঠ & Uే & $\sum^{+\infty}$ & $\stackrel{+a}{z}$ & 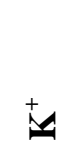 & $\mathbf{N}$ & $\mathbf{P}$ & $\mathbf{K}$ \\
\hline $\begin{array}{l}2002 / \\
2003\end{array}$ & 7.5 & 1.8 & - & 2.0 & 17.14 & 33.48 & 18.76 & 14.4 & 12.7 & 6.76 & 24.3 & 208 & 340.7 \\
\hline $\begin{array}{l}2003 / \\
2004\end{array}$ & 7.9 & 1.6 & - & 2.3 & 17.30 & 32.65 & 17.97 & 13.6 & 13.1 & 6,81 & 25.7 & 211 & 356.0 \\
\hline
\end{tabular}

* - E.C : Electric conductivity $\mathrm{m} \mathrm{mhos} / \mathrm{cm}$.

Bio- fertilizers (Nitrobien and Phosphorein) were inserted in the soil surface at the rates of 0,3 or $6 \mathrm{~g} /$ pot. Data on fresh and dry weights of flower heads / plant were recorded. Capitulums were dried under natural conditions of shade until a constant dry weight. Oil percentages were determined as described by British Pharmacopoeia (1963).Gas Liquid Chromatography (GLC) analysis of the essential oil in the second season was performed using Unicam Pro- GC equipped with flame ionization detector (FID) under the conditions of : Column with a coating film of $3 \%$ OV-17 ( Methyl phenyl Silicone ) on chromosorb - WHP.(1.5 X $4.0 \mathrm{~mm}$ and 100-120 mesh), and injector temperature of $250^{\circ} \mathrm{C}$. Nitrogen flow rate at $30 \mathrm{ml} / \mathrm{min}$, hydrogen flow rate at $33 \mathrm{ml} / \mathrm{min}$ and air flow rate at $330 \mathrm{ml} / \mathrm{min}$ with an initial temperature of $70^{\circ} \mathrm{C}-$ P.R. $8^{\circ} \mathrm{C}$ and final temperature of $200^{\circ} \mathrm{C}$, chart speed was $2 \mathrm{~min} . / \mathrm{cm}$., Range 32 as described by Bunzen et al. (1969).Total carbohydrates content was determined in the dried herb as described by Herbert et al. (1971). Nutrients were determined in the dried herb using the method described by Piper (1947). The nitrogen content was determined using the modified micro-Kjeldahl method as described by Pregl (1945); phosphorus content was estimated using the method described by King (1951). Potassium content was determined by using a Pye Unicam Model Sp Atomic Absorption Spectrophotometer.

The experimental layout was split plot design in factorial experiment. The main plot was irrigation intervals and the sub- plots were bio fertilizer treatments, including 15 treatments. Each treatment was replicated 3 times and each replicate consisted of 6 plants. The statistical analysis was carried out using Least Significant Difference ( L.S.D) test at $0.05 \%$ according to Snedecor and Cochran (1982). 


\section{RESULTS AND DISCUSSION}

\section{Fresh and dry weights of flower heads:}

Data presented in Table 1 showed that irrigation intervals affected significantly both fresh and dry weights of flowers in both seasons. Prolonging irrigation interval to 11 or 15 days significantly decreased both fresh and dry weights of flowers in both seasons. The highest fresh weight of flowers were obtained due to irrigation every 7 days (26.80 and $32.47 \mathrm{~g} /$ plant compared to irrigation every 11 days ( 16.89 and $13.89 \mathrm{~g}$ /plant ), whereas plants irrigated every 15 days gave the lowest fresh weight (11.70 and $9.02 \mathrm{~g} / \mathrm{plant}$ ) in first and second seasons, respectively. Similar results were obtained on flowers dry weight in both two seasons. These results are confirmed with, Rachad (1999) on Echinacea purpurea and Mahmoud et al. (2002) on Grindelia camporum plants.

Bio-fertilizers had a significant effect on both fresh and dry weights of flowers. In the first season, Phosphorein application at $6 \mathrm{~g} / \mathrm{pot}$ significantly increased fresh and dry weights of flowers (23.88 and $5.76 \mathrm{~g}$, respectively), compared with (15.43 and $3.73 \mathrm{~g}$, respectively) for control plants. In the second season, Nitrobien or Phosphorein application at $6 \mathrm{~g} /$ pot significantly increased fresh weight of flowers. Whereas application of both Nitrobien and Phosphorein at 3 or $6 \mathrm{~g} /$ pot significantly increased dry weight of flowers / plant. The most effective treatments were both Nitrobien and Phosphorein application at the highest rate( $6 \mathrm{~g} / \mathrm{pot})$ which gave the highest fresh and dry weights of flowers/ plant. Similar results were obtained by, Sakr (2005) on senna and Shalan (2005) on borage plants found that bio-fertilizer treatments increased fresh and dry weights of plant organs.

Interaction between irrigation intervals and bio fertilizers significantly affected both fresh and dry weights in both seasons. Irrigation at short intervals (7 days) and Phosphorein at $6 \mathrm{~g} /$ pot gave the highest fresh and dry weights of flower heads in the first season, while Irrigation every 7 days and Nitrobien at $6 \mathrm{~g} /$ pot gave the highest fresh and dry weights of flower heads in the second season.

\section{Oil percentage $(\%)$ :}

Data in Table 2 showed that, irrigation intervals significantly affected oil percentages. In the first season, irrigation at short interval (7 days) significantly increased oil percentage $(0.680 \%)$ compared with $(0.600$ and $0.435 \%)$ for irrigation at 11 or 15 days, respectively. In the second season, irrigation at 11 days interval significantly increased oil percentage $(0.720 \%)$ compared with $(0.647$ and $0.707 \%$ for short and long irrigation intervals, respectively. Similar results were obtained by Hammam (1996), on anise; found that long irrigation intervals resulted in a significant decrease in volatile oil percentage. 
Table 1. Effect of irrigation and bio-fertilizers on fresh and dry weights of flowers (g) / plant of chamomile (Matricaria chamomilla L.) plant at 2002/2003and 2003/2004 seasons.

\begin{tabular}{|c|c|c|c|c|c|c|c|c|}
\hline \multirow{4}{*}{ Bio-fertilizers (B) } & \multicolumn{8}{|c|}{ Irrigation intervals by days (A) } \\
\hline & \multicolumn{8}{|c|}{ Fresh weight } \\
\hline & \multicolumn{4}{|c|}{$2002 / 203$} & \multicolumn{4}{|c|}{$2003 / 2004$} \\
\hline & 7 & 11 & 15 & Mean & 7 & 11 & 15 & Mean \\
\hline Control & 21.09 & 15.58 & 9.62 & 15.43 & 30.45 & 13.38 & 7.94 & $\overline{17.26}$ \\
\hline N1 & 24.96 & 15.75 & 11.12 & 17.28 & 31.62 & 13.68 & 8.08 & 17.79 \\
\hline $\mathbf{N 2}$ & 26.43 & 18.71 & 11.45 & 18.86 & 34.68 & 14.24 & 8.97 & 19.30 \\
\hline P1 & 22.77 & 15.62 & 12.20 & 16.86 & 31.86 & 14.01 & 9.74 & 18.54 \\
\hline $\mathbf{P 2}$ & 38.75 & 18.80 & 14.10 & 23.88 & 33.74 & 14.15 & 10.37 & 19.42 \\
\hline Mean & 26.80 & 16.89 & 11.70 & -- & 32.47 & 13.89 & 9.02 & - \\
\hline \multicolumn{9}{|l|}{ LSD at 0.05 for: } \\
\hline (A) & 3.46 & & \multicolumn{6}{|c|}{1.02} \\
\hline (B) & 4.47 & & \multicolumn{6}{|c|}{1.32} \\
\hline A X B & 7.74 & & \multicolumn{6}{|c|}{2.30} \\
\hline & \multicolumn{8}{|c|}{ Dry weight } \\
\hline Control & 4.56 & 3.92 & 2.72 & 3.73 & 6.05 & 2.90 & 2.19 & 3.71 \\
\hline N1 & 6.32 & 4.10 & 2.88 & 4.43 & 6.29 & 3.30 & 2.27 & 3.95 \\
\hline $\mathbf{N} 2$ & 6.32 & 4.92 & 2.91 & 4.72 & 6.54 & 3.78 & 2.87 & 4.40 \\
\hline P1 & 5.11 & 3.92 & 3.24 & 4.09 & 6.25 & 2.99 & 2.70 & 3.98 \\
\hline $\mathbf{P 2}$ & 8.78 & 4.74 & 3.75 & 5.76 & 6.33 & 3.29 & 2.70 & 4.11 \\
\hline Mean & 6.22 & 4.32 & 3.10 & $\overline{---}$ & 6.29 & 3.25 & 2.55 & $\overline{---}$ \\
\hline \multicolumn{9}{|l|}{ LSD at 0.05 for: } \\
\hline (A) & 0.85 & & & & 0. & & & \\
\hline (B) & 1.11 & & & & 0.2 & & & \\
\hline A X B & 1.92 & & & & 0.4 & & & \\
\hline
\end{tabular}

$\begin{array}{ll}\mathrm{N}_{1}=\text { Nitrobien at } 3 \mathrm{~g} / \text { pot. } & \mathrm{P}_{1}=\text { Phosphorein at } 3 \mathrm{~g} / \text { pot. } \\ \mathrm{N}_{2}=\text { Nitrobien at } 6 \mathrm{~g} / \text { pot } & \mathrm{P}_{2}=\text { Phosphorein at } 6 \mathrm{~g} / \text { pot }\end{array}$

Bio-fertilizers had a significant effect on oil percentages in both seasons. Nitrobien at the two rates ( 3 or $6 \mathrm{~g} / \mathrm{pot}$ ) significantly decreased oil percentages in both seasons. Whereas Phosphorein, at the two rates (3 or $6 \mathrm{~g} /$ pot) significantly decreased oil percentages in the second season, while it had no significant effect on oil percentages in the first one compared to control. On the contrary, Youssef, et al. (2004) on celery and Heikal (2005) on thyme plant. They concluded that biofertilization treatments increased essential oil percentages. 
Table (2): Effect of irrigation intervals and bio-fertilizers on oil percentage of chamomile (dried flower heads) (Matricaria chamomilla L.) plant at 2002/2003and 2003/2004 seasons.

\begin{tabular}{|c|c|c|c|c|c|c|c|c|}
\hline \multirow{4}{*}{ Bio-fertilizers (B) } & \multicolumn{8}{|c|}{ Irrigation intervals by days (A) } \\
\hline & \multicolumn{8}{|c|}{ Oil percentage $(\%)$} \\
\hline & \multicolumn{4}{|c|}{$2002 / 2003$} & \multicolumn{4}{|c|}{$2003 / 2004$} \\
\hline & 7 & 11 & 15 & Mean & 7 & 11 & 15 & Mean \\
\hline Control & 0.667 & 0.700 & 0.500 & 0.622 & 0.560 & 1.120 & 0.731 & 0.803 \\
\hline N1 & 0.700 & 0.400 & 0.300 & 0.467 & 0.671 & 0.609 & 0.567 & 0.616 \\
\hline N2 & 0.667 & 0.500 & 0.367 & 0.511 & 0.869 & 0.770 & 0.727 & 0.788 \\
\hline P1 & 0.683 & 0.667 & 0.500 & 0.617 & 0.577 & 0.460 & 0.650 & 0.562 \\
\hline $\mathbf{P 2}$ & 0.683 & 0.733 & 0.510 & 0.642 & 0.560 & 0.640 & 0.859 & 0.686 \\
\hline Mean & 0.680 & 0.600 & 0.435 & ---- & 0.647 & 0.720 & $\mathbf{0 . 7 0 7}$ & $\overline{----}$ \\
\hline \multicolumn{9}{|l|}{ LSD at 0.05 for: } \\
\hline (A) & \multicolumn{3}{|c|}{0.041} & \multicolumn{5}{|c|}{0.007} \\
\hline (B) & \multicolumn{3}{|c|}{0.053} & \multicolumn{5}{|c|}{0.010} \\
\hline A X B & \multicolumn{3}{|c|}{0.092} & \multicolumn{5}{|c|}{0.017} \\
\hline $\begin{array}{l}\mathrm{N}_{1}=\text { Nitrobie } \\
\mathrm{N}_{2}=\text { Nitrobie }\end{array}$ & $\begin{array}{l}3 \mathrm{~g} / \mathrm{p} \\
6 \mathrm{~g} / \mathrm{p}\end{array}$ & & & $\begin{array}{l}\mathrm{P}_{1}=\mathrm{Pl} \\
{ }_{2}=\mathrm{Ph}\end{array}$ & hor & $3 \mathrm{~g}$ & & \\
\hline
\end{tabular}

Interaction between irrigation intervals and bio fertilizers significantly affected oil percentages. Plants irrigated every 7 days and treated with Nitrobien at $3 \mathrm{~g} /$ pot and control plants and irrigated every 11 days gave the highest values in both two seasons, respectively. Whereas plants treated with Nitrobien at $3 \mathrm{~g} /$ pot and irrigated every 15 days and plants treated with Phosphorein at $3 \mathrm{~g} /$ pot and irrigated every 11 days gave the lowest oil percentages in both seasons, respectively.

\section{GLC analysis of the essential oil:}

Data presented in Table 3 and Chromatograms (1,2, 3 and 4) showed that GLC analysis of chamomile oil obtained from different treatments revealed that $\alpha$ pinene, sabinene, $\rho$-cymene, 1,8-cineole, caryophyllene, bisabolon oxide A, chamazulene, bisabolol oxide $\mathrm{A}$ and dicycloether are the main components separated from chamomile oil. The major components are $\alpha$ pinene which ranged from 26.11 to $5.94 \%$, sabinene which ranged from 21.93 to $4.10 \%$ and bisabolol oxide a which ranged from 55.81 to $2.62 \%$. Similar results are obtained by Massoud and Franz (1990) mentioned that different chemocultivars of chamomile are presented on the market, which differ in the composition of the essential oil. For example, bisabolol Atype presented in Egypt, Czech. Rep. and Hungary, bisabolol-type is presented in Spain and bisabolon oxide type is presented in Turkey and Bulgaria. Lawless (1992) showed that chamazulene, farnesene, bisabolol oxide, dicycloether, among others are the main components of chamomile oil (Chamazulene is not present in the fresh flowers, but is only produced during the process of distillation).

Irrigation every 7 days gave the highest $\alpha$ pinene, sabinene, $\mathrm{p}$ cymene, 1,8cineole, bisabolon oxide A, chamazulene and dicycloether compared with the other 
Table 3. GLC analysis of the essential oil of chamomile ( Matricaria chamomilla,L. ) plants in the second season 2003/2004.

\begin{tabular}{|c|c|c|c|c|c|c|c|c|c|c|}
\hline 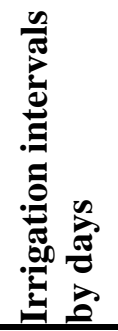 & 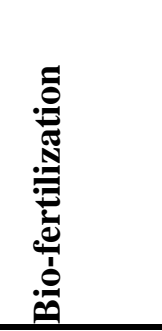 & 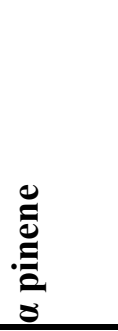 & 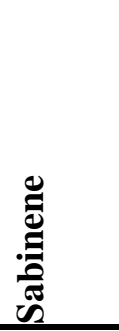 & 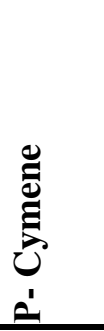 & 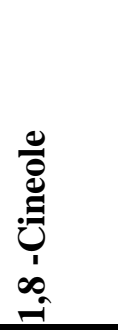 & 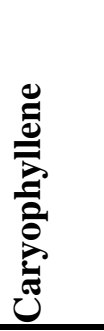 & 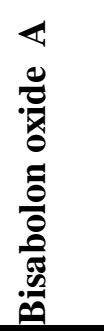 & 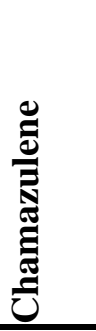 & 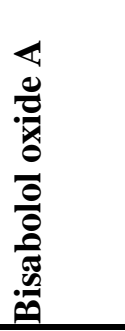 & 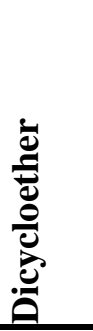 \\
\hline \multirow{6}{*}{7} & Control & 13.28 & 8.89 & 7.27 & 5.58 & 5.08 & 9.66 & 2.38 & 23.41 & 8.35 \\
\hline & N1 & 25.76 & 16.86 & 14.05 & 9.31 & 2.46 & 0.67 & 0.33 & 16.60 & 0.65 \\
\hline & N2 & 19.02 & 13.68 & 14.30 & 10.54 & 3.84 & 2.37 & 0.48 & 16.78 & 1.52 \\
\hline & P1 & 17.80 & 12.66 & 13.39 & 9.20 & 3.94 & 2.41 & 0.44 & 10.05 & 1.21 \\
\hline & $\mathbf{P 2}$ & 25.05 & 21.93 & 12.59 & 8.93 & 1.41 & 0.51 & 1.86 & 8.57 & 0.94 \\
\hline & Mean & 20.16 & 14.80 & 12.32 & 8.71 & 3.35 & 3.12 & 1.10 & 15.08 & 2.53 \\
\hline \multirow{6}{*}{11} & Control & 26.22 & 11.56 & 18.67 & 13.67 & 3.73 & 0.47 & 0.48 & 2.62 & 0.27 \\
\hline & N1 & 5.94 & 3.18 & 4.71 & 3.58 & 3.04 & 3.57 & 1.24 & 41.62 & 3.10 \\
\hline & N2 & 11.44 & 13.86 & 1.74 & 0.87 & 1.24 & 2.88 & 1.60 & 55.81 & 3.27 \\
\hline & P1 & 6.72 & 4.10 & 13.70 & 10.42 & 6.69 & 0.91 & 0.15 & 24.94 & 1.70 \\
\hline & $\mathbf{P 2}$ & 23.35 & 21.83 & 13.85 & 10.02 & 1.92 & 3.50 & 1.03 & 10.38 & 1.04 \\
\hline & Mean & 14.73 & 10.91 & 10.53 & 7.71 & 3.32 & 2.27 & 0.90 & 27.07 & 1.88 \\
\hline \multirow{6}{*}{15} & Control & 19.03 & 12.95 & 13.03 & 8.95 & 3.66 & 2.94 & 0.28 & 10.46 & 1.45 \\
\hline & N1 & 25.59 & 12.38 & 15.25 & 9.91 & 3.96 & 0.92 & 0.26 & 14.02 & 0.85 \\
\hline & N2 & 14.24 & 9.50 & 12.75 & 8.01 & 4.69 & 3.90 & 0.18 & 6.14 & 0.59 \\
\hline & P1 & 21.24 & 15.71 & 14.44 & 10.62 & 2.67 & 1.52 & 0.13 & 12.80 & 1.03 \\
\hline & $\mathbf{P 2}$ & 20.55 & 2.48 & 1.08 & 0.92 & 4.66 & 5.02 & 1.52 & 45.86 & 4.10 \\
\hline & Mean & 20.13 & 10.60 & 11.31 & 7.68 & 3.93 & 2.86 & 0.47 & 17.86 & 1.60 \\
\hline \multicolumn{2}{|c|}{ Mean of control } & 19.51 & 11.13 & 12.99 & 9.40 & 4.16 & 4.36 & 1.05 & 12.16 & 3.36 \\
\hline \multicolumn{2}{|c|}{ Mean of N1 } & 19.07 & 10.81 & 11.34 & 7.60 & 3.05 & 1.72 & 0.61 & 24.08 & 1.53 \\
\hline \multicolumn{2}{|c|}{ Mean of N2 } & 14.90 & 12.35 & 9.60 & 6.47 & 3.26 & 3.05 & 0.75 & 26.24 & 1.79 \\
\hline \multicolumn{2}{|c|}{ Mean of P1 } & 15.25 & 10.82 & 13.84 & 10.08 & 4.43 & 1.61 & 0.24 & 15.93 & 1.31 \\
\hline \multicolumn{2}{|c|}{ Mean of $P 2$} & 22.98 & 15.41 & 9.17 & 6.62 & 2.66 & 3.01 & 1.47 & 21.60 & 2.03 \\
\hline
\end{tabular}

irrigation intervals. Whereas irrigation every 11 days gave the highest percentages of bisabolol oxide a. These results are in harmony with those obtained by Shoala (1992) showed that irrigation every 20 days gave the highest citral a and $b$ contents in lemongrass oil. Hammam (1996) on anise, found that irrigation every 2 or 4 weeks gave higher anethol and $\alpha$ pinene than irrigation every 6 weeks.

Bio-fertilizers ( Nitrobien and Phosphorein ) affecting the main components of the essential oil. Nitrobien at 3 or $6 \mathrm{~g} /$ pot gave the highest bisabolol oxide A 


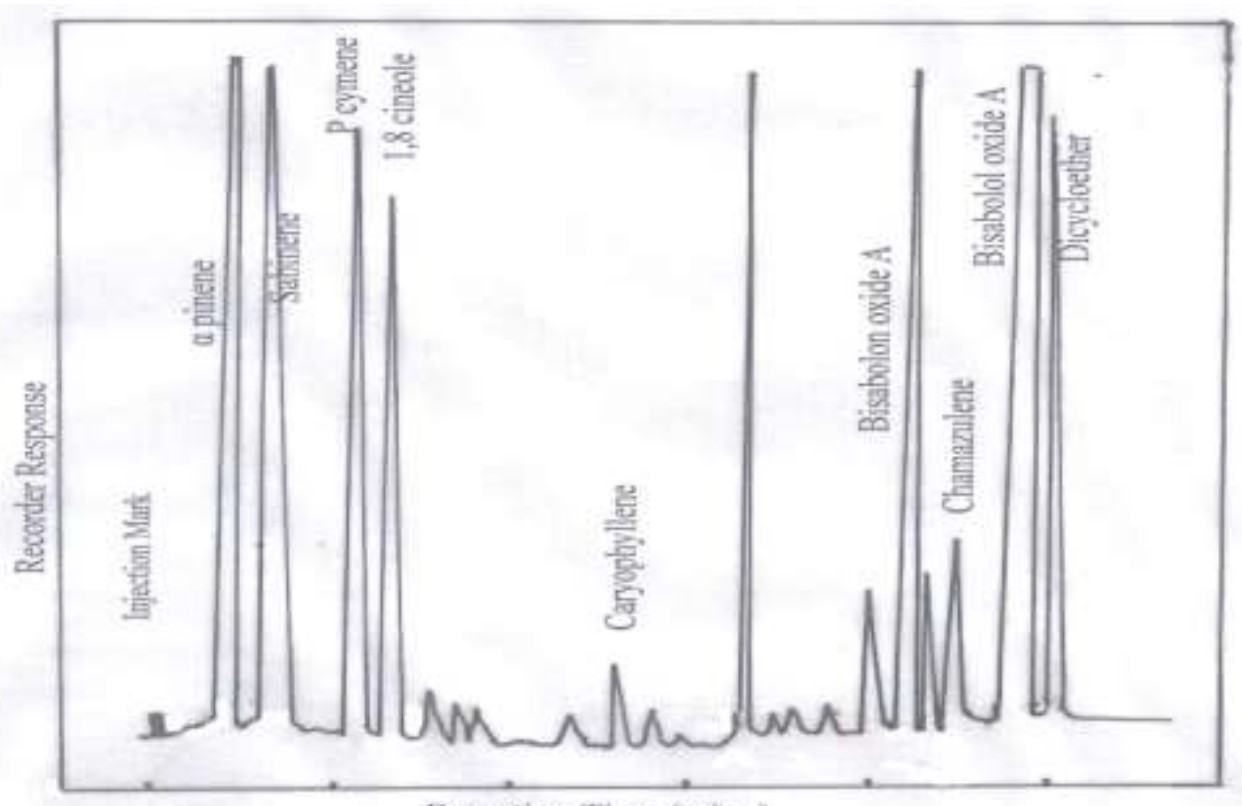

Retention Time (min. )

Fig (1) : Chromatogram of chamomile (Aforricario chamomillat essential oil distilled from eontrol plants irrixated every 7 dinys

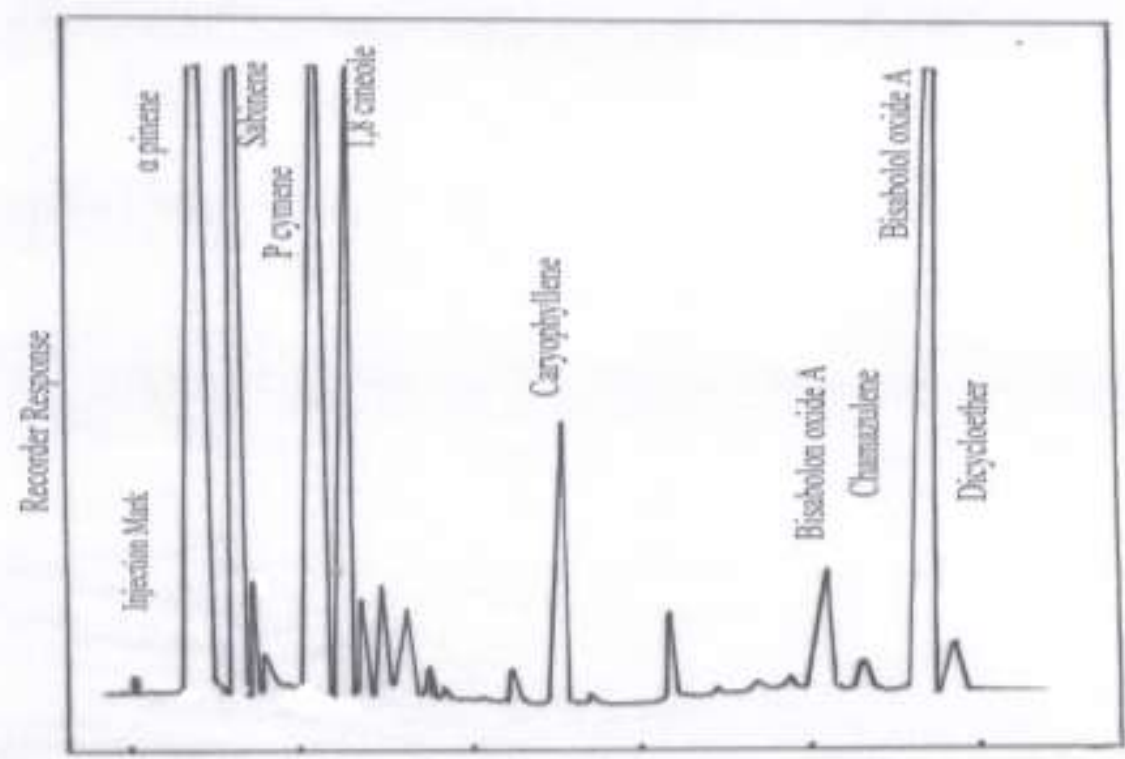

Retention Time (min.)

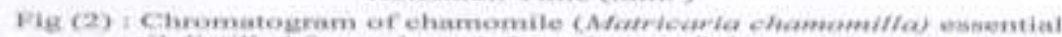
oil distilled from plants frrieated every 7 days and treated with Nitrobien at 6 erm pot 


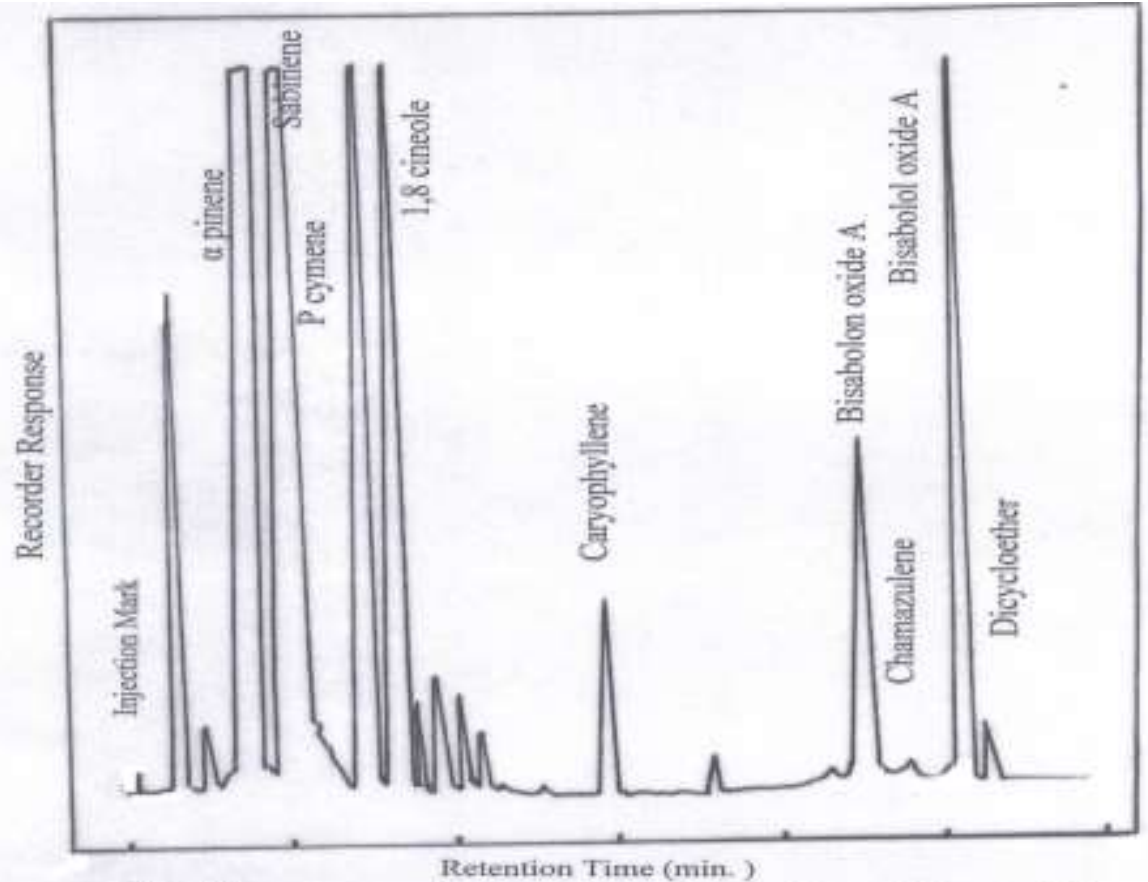

Fig (3) : Chromatogram of chamomile (Aforricaria chamomilla) essential ofl distilled from plants irrigated every 11 days and treated with Phosphorein at $6 \mathrm{gm} / \mathrm{pot}$.

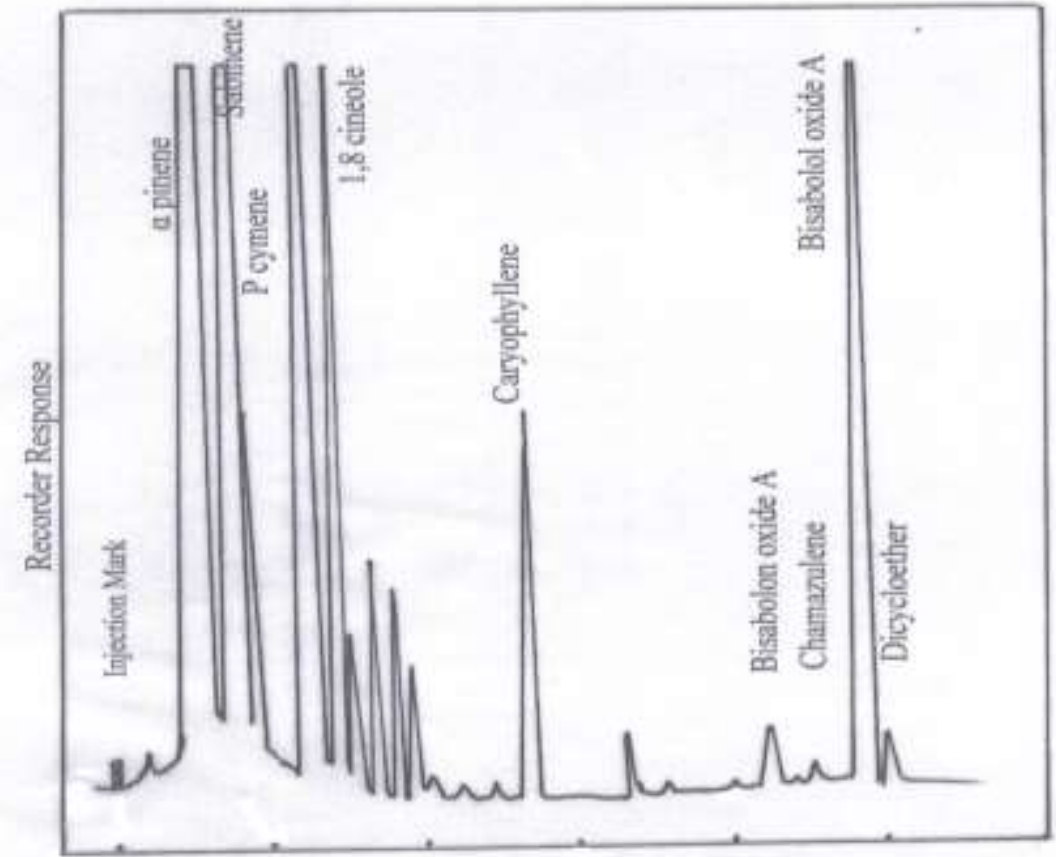

Retention Time (min.)

Fie (4) : Chromatogram of chamomile (Afatricarla chamomilia) essential oil distilled from plants irrigated every is days and treated with Nitrobien at $3 \mathrm{gm} / \mathrm{pot}$ 
contents in chamomile oil. Whereas Phosphorein at $3 \mathrm{~g} /$ pot resulted in the highest $\rho$ cymene, 1,8- cineole and caryophyllene percentages. Phosphorein at the highest rate (6 g /pot) gave the highest $\alpha$ pinene, sabinene and chamazulene compared with control. The highest bisabolon oxide A and dicycloether percentages were obtained in the essential oil distilled from unfertilized plants. Similar results are obtained by Mahfoz (2003) found that the main compounds increased in marjoram oil as a result of using bio-fertilizers. Heikal (2005) showed that thymol content in thyme oil was increased by active dry yeast application.

\section{Plant constituents:}

\section{- Elements contents:}

Date presented in Table 4 showed that, irrigation every 11 days gave the highest $\mathrm{N}$ contents followed by 15 days irrigation treatment. Irrigation every 15 days gave the highest $\mathrm{P}$ and $\mathrm{K}$ contents followed by 11 days irrigation treatment compared with the shortest irrigation intervals ( every 7 days) which gave the lowest $\mathrm{N}, \mathrm{P}$ and $\mathrm{K}$ contents. This effect may be due to the leaching of elements from the soil media. Similar results were obtained by Rachad (1999) on Echinacea purpurea, reported that weekly irrigation gave the highest contents of nitrogen, phosphorus and potassium in the plants. Hammoda (2001), on moghat, found that prolonging the irrigation intervals enhanced $\mathrm{N}, \mathrm{P}$ and $\mathrm{K}$ contents in different plant organs.

Bio- fertilization treatments ( Nitrobien or Phosphorein ) each at 3 or $6 \mathrm{~g} / \mathrm{pot}$ increased both $\mathrm{P}$ and $\mathrm{K}$ contents in most cases compared with the control. Also, Nitrobien at $6 \mathrm{~g} /$ pot and Phosphorein at $3 \mathrm{~g} /$ pot in the first season, and both Nitrobien and Phosphorein at 3 or $6 \mathrm{~g} /$ plant in the second season increased nitrogen contents compared with unfertilized plants. Similar results were obtained by Heikal (2005) on thyme and Sakr (2005) on senna plants, found that bio-fertilizers increased $\mathrm{N}, \mathrm{P}$ and $\mathrm{K}$ contents.

Interaction between irrigation every 15 days and Nitrobien at $6 \mathrm{~g} /$ pot gave the highest $\mathrm{N}$ content in the first season, while plants irrigated every 11 days and treated with Phosphorein at $3 \mathrm{~g} /$ pot gave the highest $\mathrm{N}$ content in the second season. Phosphorein at $6 \mathrm{~g} /$ pot combined with irrigation every 7 or 11 days gave the highest $\mathrm{P}$ contents in both seasons, respectively. Phosphorein treatment at $3 \mathrm{~g} / \mathrm{pot}$ and irrigation every 15 days in the first season and Nitrobien at $6 \mathrm{~g} /$ pot and irrigation every 11 days treatment in the second season gave the highest $\mathrm{K}$ contents.

\section{Total carbohydrates contents:}

Data in Table 4 show that irrigation every 7 days gave the highest total carbohydrates contents followed by irrigation at long interval (15 days) compared with irrigation every 11 days treatment which gave the lowest values in both seasons. Confirmed results were observed by Hammam (1996) on anise showed that prolonging the irrigation intervals (6 weeks) reduced the total carbohydrates content and Rachad (1999) on Echinacea purpurea, reported that weekly irrigation gave the highest total carbohydrates contents in the plants. 
Table 4. Effect of irrigation intervals and bio-fertilizers on nitrogen, phosphorus, potassium and total carbohydrates contents of chamomile (Matricaria chamomilla L.) plants at 2002/2003and 2003/2004 seasons.

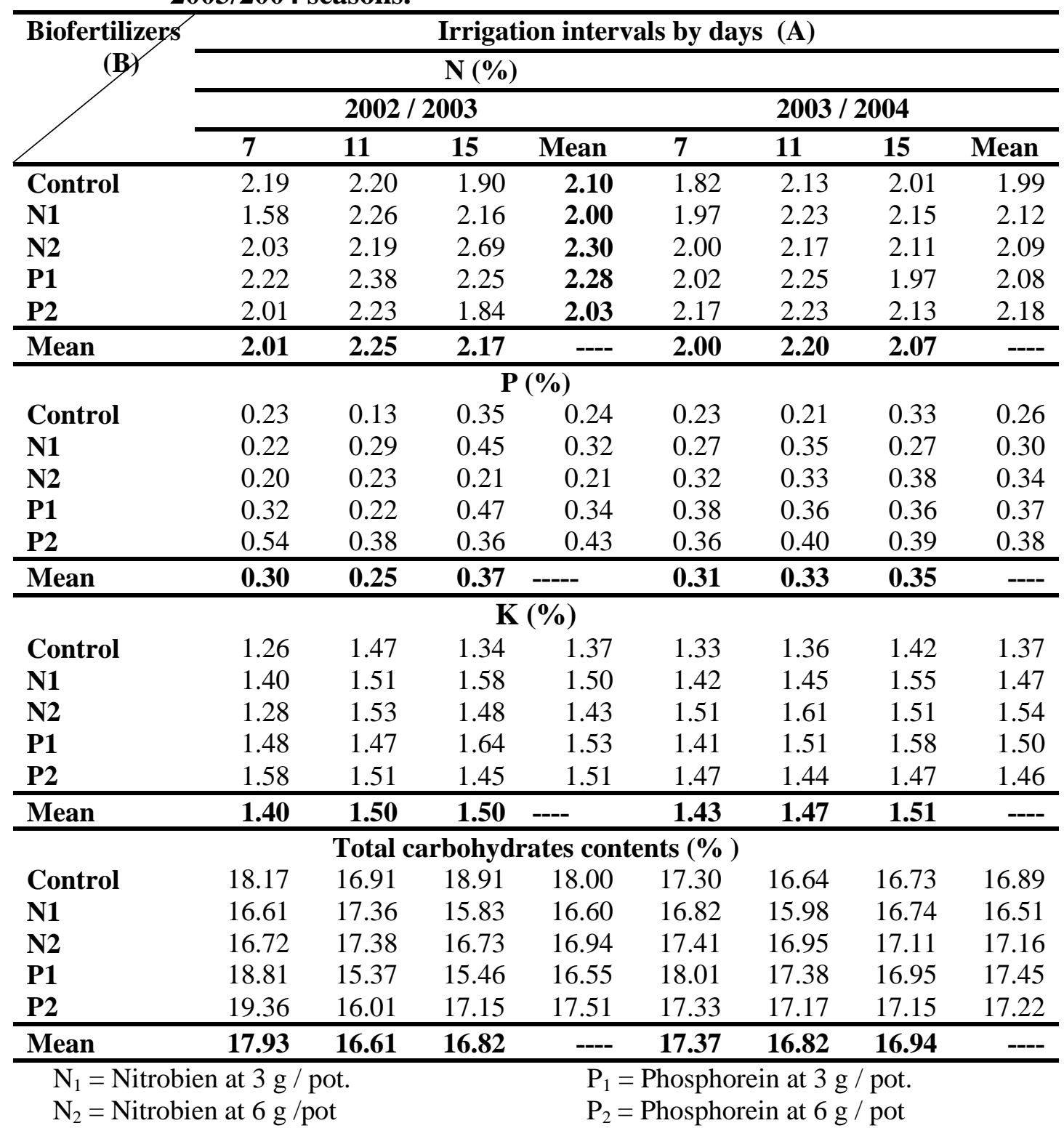

Bio-fertilizers (Nitrobien and Phosphorein ) at 3 or $6 \mathrm{~g} /$ plant decreased total carbohydrates contents in the first season, while in the second one an opposite trend was observed, i.e. Nitrobien at $6 \mathrm{~g} /$ pot and Phosphorein at $3 \mathrm{or} 6 \mathrm{~g} /$ pot increased total carbohydrates contents. These results are in agreement with those obtained by Heikal (2005) on thyme plant, found that total carbohydrates, soluble and non soluble sugars contents were increased by the application of active dry yeast especially at the 
rate of $40 \mathrm{~g} / \mathrm{L}$. and Sakr (2005) on senna plants, found bio-fertilizers increased total carbohydrates in leaves, pods, stems, branches and root system.

Interaction between Phosphorein at $6 \mathrm{~g} /$ pot or $3 \mathrm{~g} /$ pot and irrigation every 7 days gave the highest total carbohydrates contents in the two seasons, respectively. Whereas Phosphorein at $3 \mathrm{~g} /$ pot plus irrigation every 15 days in the first season, and Nitrobien at $3 \mathrm{~g} /$ pot and irrigation every 11 days in the second season gave the lowest total carbohydrates contents.

\section{Recommendation :}

From the above mentioned results, it can be recommended that, chamomile (Matricaria chamomilla) plants should be irrigated every 7 days and fertilized with Nitrobien and Phosphorein at $6 \mathrm{~g} /$ pot to increase the yield, oil production and high main essential oil components.

\section{REFERENCES}

Ahmed, A. A. M. and G. M. El-Hassen (2001): Effect of water regime and cultivar on herbage yield and alkaloid content of Catharanthus roseus. J. of Medi. and Arom. Plant Sci., 23: (3), 350-356.

Akbarinia, A. ; M. Khosravifard ; E. S. Ashoorabadi and P. Babakhanlou (2005): Effects of irrigation interval on the yield and agronomic characteristics of black cumin (Nigella sativa). Iranian J. of Med. Arom. Plants Res., 21(1): 65-73.

British Pharmacopoeia (1963): Determination of volatile oil in drugs. The Pharmaceutical Press 17 Bloomsbury. Square London, W.C.L.

Bunzen,J. ; N. Guichard ; J. Labbe ; P. Prevot ; J. Sperpinet and J. Trenchant (1969): Practical Manual of Gas Chromatography. El- Seiver Publ.Com., Amesterdam, London.

Hammam, K. A. (1996): Effect of nitrogenous fertilization and irrigation on growth, yield and active constituents of anise plants (Pimpinella anisum,L.). M. Sc. Thesis, Fac. Agric., Cairo Univ.

Hammam, K. A. (2002): Effect of irrigation intervals and chemical fertilization on growth, yield and chemical constituents of Cassia acutifolia plants. Ph.D. Thesis, Fac. Agric., Cairo Univ.

Hammoda, S. S. M. (2001): Effect of some agricultural treatments on growth and productivity of moghat plant under Sinai conditions. M. Sc. Thesis, Fac. Agric., Cairo Univ.

Heikal, A., A. M. (2005): Effect of organic and bio-fertilization on growth, production and composition of thyme (Thumus vulgaris, L.) plants. M. Sc. Thesis, Fac. Agric., Cairo Univ.

Herbert, D.; P. J. Phipps and R. E. Strange (1971): Determination of total carbohydrates. Methods in Microbiology, 5 (B): 290 - 344. 
King, E. J. (1951): Micro- Analysis in Medical Biochemistry. $2^{\text {nd }}$ Ed., Churchill publishing Co., London.

Lawless, J. (1992): The Encyclopaedia of Essential Oils. Element Books Limited, Longmead, Shaftesbury, Dorset, London, USA, Element, Inc.42 Broadway. Rockport, MA 01966, 78-79.

Mahfoz, S. A. (2003): Effect of bio-fertilization on growth and oil production of marjoram (Marjorana hortensis, Moench) plant. Ph. D. Thesis, Fac. Agric., Cairo Univ.

Mahmoud, S.M.; J. Bernath ; E. Zamborine-Nemeth ; L. Craker and O. Kock (2002): Effect of water stress and NPK fertilization on growth and resin content of Grindelia camporum, Greene. Acta Hortic., No.576, 289-294.

Massoud H. Y. and C. Franz (1990): Quantitative genetical aspects of Chamomilla recutita, L. II Genotype environment interactions and proposed breeding methods. J. Ess. Oil Res., 2 : 299- 305.

Mastro, G. de.; G. Manolio and V. Marzi (2004): Jerusalem artichoke (Helianthus tuberosus L.) and chicory (Cichorium intybus, L.): potential crops for inulin production in the Mediterranean area. Acta Horti., (629): 365-374.

Mazrou, M. M.; M. M. Afify; H. E. Wahba ; M. A. Mohamed; M. A. Eraki and S. Mahfouz (2002): Effect of irrigation and Vapor Gard on growth, yield and chemical composition of roselle plant. Bull. of the National Res. Centre Cairo., 27 (4):533-548.

Migahed, H. A.; A. E. Ahmed and B. F. Abd-El-Ghany (2004): Effect of different bacterial strains as bio-fertilizer agents on growth, production and oil of Apium graveolens under calcareous soil. Arab Univ. J. of Agric. Sci.; 12 (2): 511-525.

Piper C. S. (1947): Soil and Plant Analysis. pp 258 - 275. Univ. of Adelaida, Adelaida. Australia.

Pregl, P. (1945): Quantitative Organic Microanalysis. $4^{\text {th }}$ Ed. Churchill, London.

Rachad, S. H. (1999): Effect of some agricultural practices on the growth, yield and active ingredients of Echinacea plant "Echinacea purpurea". M. Sc. Thesis, Fac. Agric., Cairo Univ.

Sakr, W. R. A. S. (2005): Effect of organic and bio-fertilization on growth and active constituents production senna plants. M. Sc. Thesis, Fac. Agric., Cairo Univ.

Salman, A. S. (2004): Effect of bio-fertilization on Ocimum basilicum, L. plant. M. Sc. Thesis, Fac. Agric., Cairo Univ.

Saraf, R.K. and J. P. Tiwari (2004): Influence of integrated nutrient management on growth and yield of main and ratoon crop of muskdana (Abelmoschus moschatus). J. of Medicinal and Aromatic Plant Sciences., 26 (1): 24-27.

Shalan, M. N.(2005): Effect of compost and different sources of biofertilizeres, on borage plants (Borago officinalis, L.). Egypt. J. of Agric. Res., 83 (1): 271284.

Shoala, A. W. T. (1992): Effect of irrigation and chemical fertilization treatment on lemon grass (Cymbopogon citratus, L.) plants. M. Sc. Thesis, Fac. Agric., Cairo, Univ. 
Singh, M. (2004): Effects of plant spacing, fertilizer, modified urea material and irrigation regime on herbage, oil yield and oil quality of rosemary in semiarid tropical conditions. J. Hort. Sci. and Biotechnology, 79(3): 411-415.

Singh, M. and S. Sharma (2001): Influence of irrigation and nitrogen on herbage and oil yield of palmarosa (Cymbopogon martinii) under semi-arid tropical conditions. European J. of Agronomy, 14 (2):157-159.

Snedecor, G. W. and W. G. Cochran (1980): Statistical Methods. $6^{\text {th }}$ Ed., The Iowa State Univ., Press, Iowa, U.S.A.

Yassen, M.; P. Ram; A. Yadav and K. Singh (2003): Response of Indian basil (Ocimum basilicum) to irrigation and nitrogen schedule in Central Uttar Pradesh. Annals of Plant Physiology,17(2):177-181.

Youssef, A. A.; A. E. Edris and A. M. Gomaa (2004): A comparative study between some plant growth regulators and certain growth hormones producing microorganisms on growth and essential oil composition of Salvia officinalis, L. plants. Annals of Agric. Sci. Cairo., 49 (1): 299-311.

Zayed, A. A.; S. M., Sleim; M. A. Hassanain and Y. A. M. Hafez (2004): Effect of sowing spacings, nitrogenous and bio-fertilization treatments on yield and chemical composition of borage plants (Borago officinalis, L). Egyptian. J.Agric. Res., 82 (2): 187-206. 


\section{تأثير فترات الري والتسميا الحيوي علي المحصول وإنتاج الزيت والتركيب الكيماوي في نباتات البابونج}

\section{قسم بساتين الزينة ـ ـ كلية الزيثية الزراعة - جامعة القاهرة.}

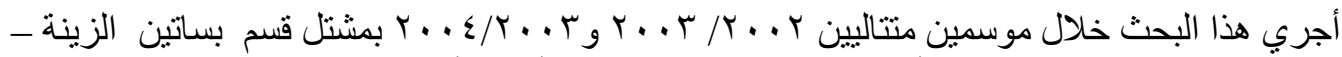

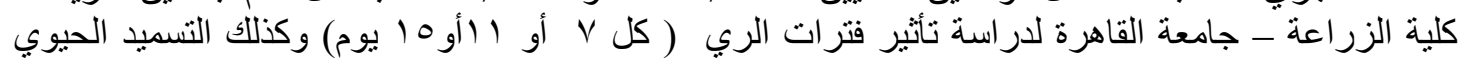

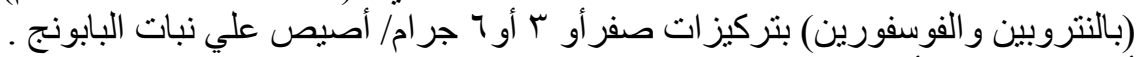

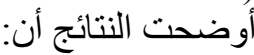
إطالة فترات الري إلي الأو 10 يوم أدت إلي نقص معنوي في الوزن الطازج و الجاف في النورات في

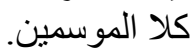

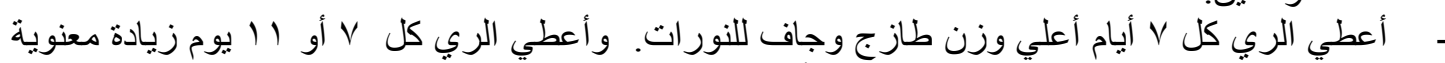

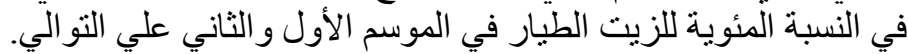

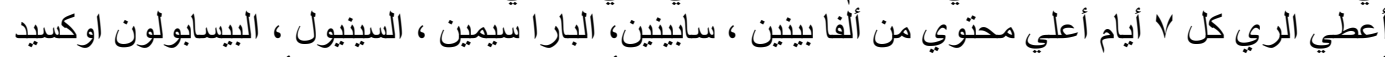

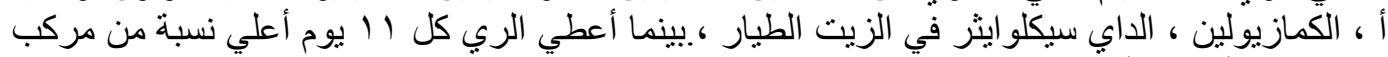

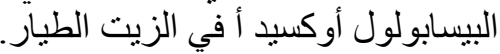

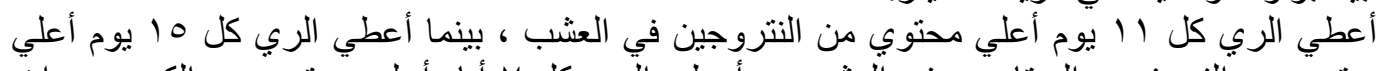

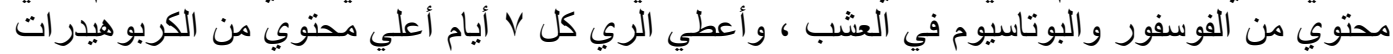
الكلية.

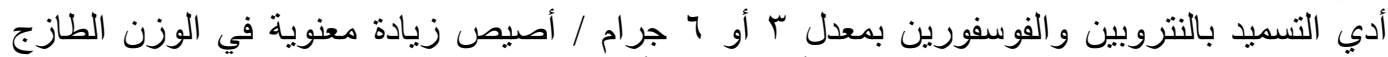

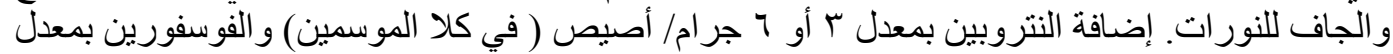

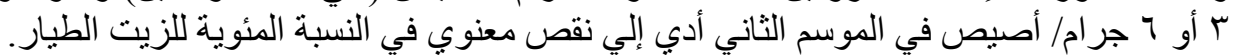

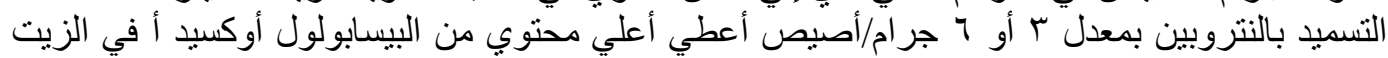

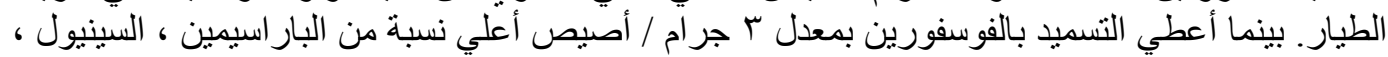

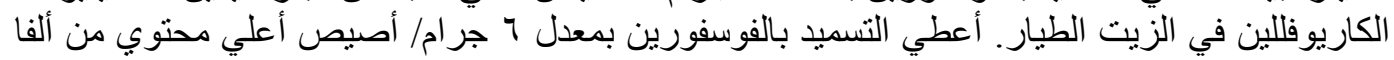
بينين ، سابينين ، الكمازيولين في الزين الزيت الطين الطيار.

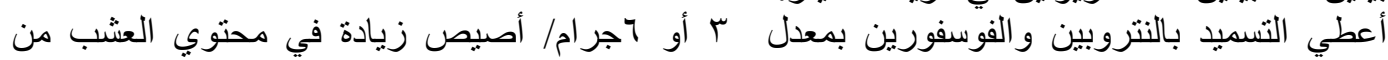

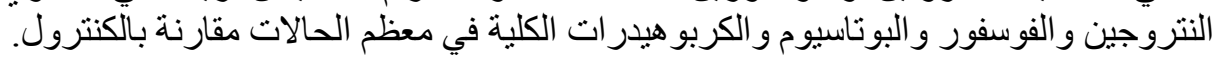

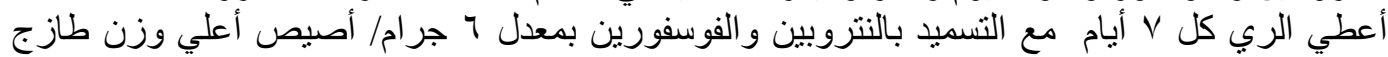

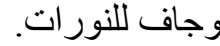

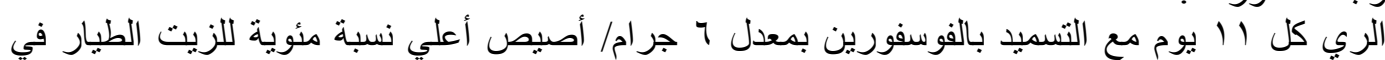

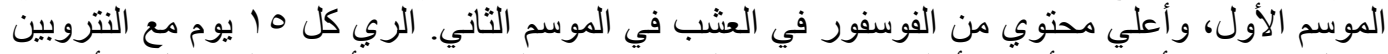

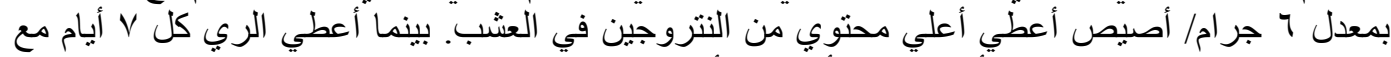

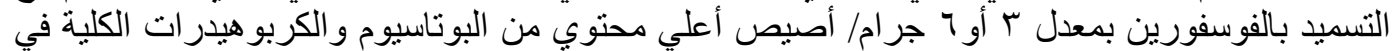

